Louisiana State University

LSU Digital Commons

Faculty Publications

Department of Oceanography \& Coastal

Sciences

6-2006

Will Lowering Estuarine Salinity Increase Gulf of Mexico Oyster

Landings?

R. Eugene Turner

Follow this and additional works at: https://digitalcommons.Isu.edu/oceanography_coastal_pubs

Digitart of the Oceanography Commons

Commons

Network

Logo 


\title{
Will Lowering Estuarine Salinity Increase Gulf of Mexico
}

\section{Oyster Landings?}

\author{
R. E. TURnER* \\ Coastal Ecology Institute, Louisiana State University, Baton Rouge, Louisiana 70803
}

\begin{abstract}
Previous studies provide conflicting opinions on whether lower than average salinities in Gulf of Mexico (GOM) estuaries are likely to increase or decrease oyster harvests (Crassostrea virginica), which represented $69 \%$ and $54 \%$ of the United States oyster landings by weight, and dockside value, respectively, in 2003. The present study examined a 54-yr record (1950-2003) of oyster harvests and river discharge in five major estuaries in GOM states (Florida, Alabama, Mississippi, Louisiana, and Texas). Oyster landings were inversely related to freshwater inflow. Peaks in landings, 21 of 23 in West Florida, Alabama, Mississippi, and Texas combined, were coincidental with lows in river discharge from the major rivers in the estuaries. Lows in landings in these states (17 of 19) coincided with peaks in discharge of the major rivers feeding their estuaries. Landings in Breton Sound, Louisiana, were also inversely related to river discharge. The only exception to this pattern was for landings in the Plaquemines Parish, Louisiana, part of the Breton Sound estuary, where there were higher landings following increased Mississippi River discharge. The Bonnet Carré spillway, completed in 1931, diverts flood waters from the Mississippi River to Lake Pontchartrain, and it has been opened to reduce flood heights in 1937, 1950, 1973, 1975, 1979, 1983, and 1997. Twenty-five of 28 times after the spillway was opened, oyster landings in Mississippi were lower than in the other four states. The inverse relationship between freshwater inflow and oyster landings suggests that the proposed Bonnet Carré Freshwater Project, designed to reduce estuarine salinity, cannot be justified on the basis of anticipated higher oyster yields in Mississippi or Louisiana. Manipulating estuarine salinity in the GOM should be done within the context of the whole estuary and not just part of the estuary.
\end{abstract}

\section{Introduction}

Natural oyster beds of the eastern oyster, Crassostrea virginica, are located within a salinity range of 10 to $30 \mathrm{psu}$ in Gulf of Mexico estuaries (Berrigan et al. 1991). Salinity is a physiological constraint on the oyster, their competitors for space, and oyster predators, e.g., parasites (Perkinus marinus), southern oyster drill (Stramonita haemastoma), boring sponges (Cliona sp.), and boring clams (Diplothyra smithii). Oyster drill, for example, are found where salinity is $>15$ psu (Butler 1954). Salinity also represents an indirect measure of the food supply that is filtered with various efficiencies dependent upon the suspended matter concentration and the dilution of land-based pollutants. The temporal and spatial variability of estuarine salinity is dependent on water supply, evaporation, and mixing, and also management, which includes the direct influence of activities such as water withdrawal for inland irrigation projects and diversions, and the indirect effects of global climate change.

The optimal salinity zone for oyster yields in an estuary is bounded by low and high salinities, with an intermediate zone of high yields in between (Fig. 1). Because the open ocean is the dominant diluent of the freshwater entering an estuary, the

\footnotetext{
*Corresponding author; tele: 225/578-6454; fax: 225/5786326; e-mail: euturne@1su.edu
}

position of the freshwater boundary for optimal oyster harvest will likely be more variable than the position of the saltwater boundary. For oyster reefs on the high salinity side of the optimization curve, freshening the estuary may result in higher yields or lower yields, depending on whether salinity declines along the ascending or descending side of the optimization curve, respectively (Fig. 1 lines A and B). The potential yields will be reduced with any amount of freshening for oyster reefs located on the freshwater side of the curve (line $\mathrm{C}$ ). Oyster reefs are situated across this optimization curve in most estuaries, although some locations will be closed to harvest. The influence of salinity on oyster establishment, growth, and commercial yield are not necessarily constant throughout the life cycle. Oysters grow faster in areas with fluctuating salinities within their normal ranges, compared to constant salinity (Pierce and Conover 1954). The effects of altered salinities may be different from one season to another and the optimization curve will be widened or constrained accordingly.

The question addressed in this paper is whether or not the average oyster yield for an estuary is on the ascending or descending portion of the curve shown in Fig. 1. Conclusions about the effects of freshening estuaries on oyster harvests may be contradictory for the same estuary and are often rather sparsely supported by data on the actual landings. These contradictions and uncertainties 


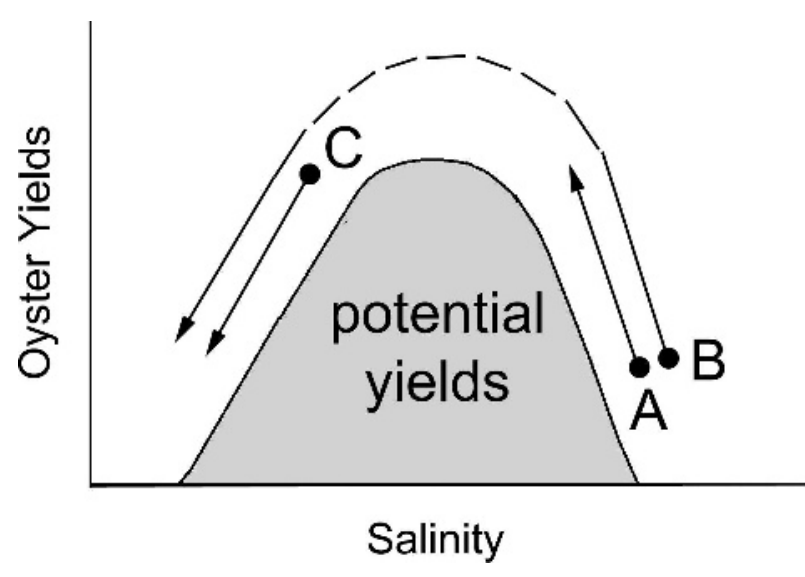

Fig. 1. The hypothesized effect of freshwater inflow on average oyster yields for the whole estuary. Natural oyster reefs in the Gulf of Mexico exist within a salinity zone of 10 to $30 \mathrm{psu}$. For oyster reefs on the high salinity side of the optimization curve, freshening the estuary may result in higher yields (line A) or lower yields (line B), depending on how low the salinity falls when freshwater flow into the estuary increases. Potential yields will be reduced with any amount of freshening for oyster reefs located on the freshwater side of the optimum curve (line $\mathrm{C}$ ).

form a basis for the comparative analysis of Gulf of Mexico estuaries attempted in this paper and indicate the degree of interest in the topic by the management and user communities.

Powell et al. (2003) noted that a common interpretation by managers interested in increasing oyster harvests is that "If a rule of thumb exists for oysters and freshwater inflow, it is that an increase in saltwater intrusion will result in a reduction in oyster production." (p.102). A review of relevant papers reveals some outstanding inconsistencies. Ulanowicz et al. (1980) constructed an empirically accurate model that included an inverse relationship between salinity and oyster yields for the middle of Chesapeake Bay, and Allen and Turner (1989) described an inverse relationship between the harvest in Apalachicola Bay and river flow in winter-spring, implying that higher salinities were related to higher harvests. Authors of several studies suggest that major floods were detrimental to oyster yields in Mobile Bay (Galtstoff 1930; May 1972), Mississippi Sound (Butler 1949, 1952; Butler and Engle 1950), and Texas (Hofstetter 1981; Marwitz and Bryan 1990). Powell et al. (2003) constructed a hydrodynamic oyster population model that included several life stages of the oyster and its parasites. The model predicted that a freshwater diversion would have a negative effect on oyster yields for a portion of Galveston Bay resulting from a "disequilibrium between geography and salinity brought about by freshwater diversion. Although the bay hydrology shifts, available hard substrate does not" (Powell et al. 2003, p. 119).

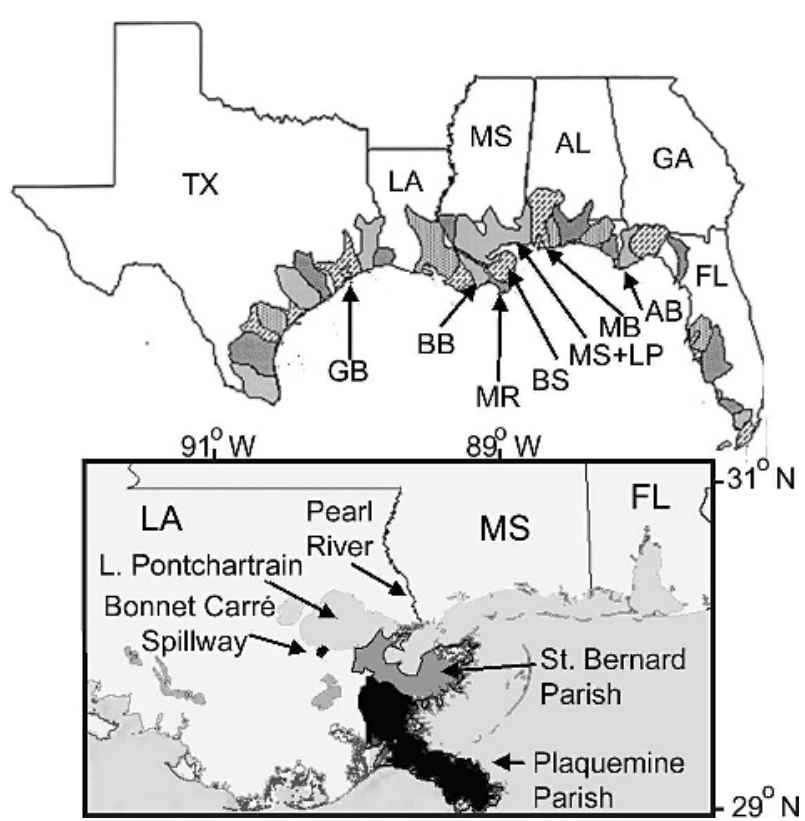

Fig. 2. Estuaries of the Gulf of Mexico (GOM) and the geographic features mentioned in the text. Top: Estuaries of the GOM shaded to distinguish their drainage basin. The abbreviations for the estuaries are: $\mathrm{GB}=$ Galveston Bay; $\mathrm{BB}=$ Barataria Bay; $\mathrm{MR}=$ Mississippi River; BS = Breton Sound; MS + LP = Mississippi Sound and Lake Pontchartrain; $\mathrm{MB}=$ Mobile Bay; $\mathrm{AB}$ = Apalachicola Bay. Bottom: the location of the Bonnet Carré spillway between the Mississippi River and Lake Pontchartrain, St. Bernard Parish and Plaquemines Parish.

Others suggest that river diversions will increase oyster harvests. Viosca (1938) thought that the 1937 opening of the Bonnet Carré, a diversion of the Mississippi River into Lake Pontchartrain and nearby Mississippi Sound (Fig. 2), would be beneficial to the oyster harvests, reflecting the commonly-held conclusion of managers and some scientists that freshening estuaries enhanced oyster harvest (Gunter 1953; Etzold and Williams 1974). The State of Louisiana had a different opinion at one point, and successfully lobbied Congress for funds to compensate for the loss of fisheries yields caused by the 1946 opening of the Bonnet Carré (U.S. Congress House 1948).

These are not trivial digressions within the context of public works projects. A large engineering project to intentionally freshen Mississippi Sound with a new Bonnet Carré diversion has been under consideration for several decades (and with varying degrees of support). The Bonnet Carré spillway protects the city of New Orleans by diverting floodwaters from the Mississippi River to Lake Pontchartrain and into Mississippi Sound at the mouth of the Pearl River, which is the southern border between Louisiana and Mississippi. The 3,450 ha spillway was completed in 1931, has 
TABLE 1. Year, duration, and maximum flow of each opening of the Bonnet Carré.

\begin{tabular}{cllc}
\hline & \multicolumn{2}{c}{ Open } & \multirow{2}{*}{ Maximum Flow } \\
Fear & \multicolumn{1}{c}{ To: } & \multicolumn{1}{c}{ MS) } \\
\hline 1937 & January 30 & March 7 & 5,974 \\
1945 & March 23 & May 18 & 9,003 \\
1950 & February 10 & March 19 & 6,313 \\
1973 & April 8 & June 21 & 5,521 \\
1975 & April 14 & April 26 & 3,114 \\
1979 & April 18 & May 21 & 5,407 \\
1983 & May 20 & June 23 & 7,489 \\
1997 & March 17 & April 18 & 6,880 \\
\hline
\end{tabular}

a designed capacity of $7,080 \mathrm{~m}^{3} \mathrm{~s}^{-1}$, and has been used to reduce floodwater heights in 1937, 1950, 1973, 1975, 1979, 1983, and 1997 (Table 1). The average diversion opening is enough to fill the lake volume several times and to triple the annual nitrogen loading within the one to three month discharge event (Turner et al. 2002). A congressionally-approved \$99 million project, the Bonnet Carré Freshwater Diversion Project, is meant to reduce saltwater intrusion and increase annual oyster landings by 0.9 and 2.6 million $\mathrm{kg}$ in Mississippi and Louisiana, respectively. The Assistant Secretary of the Army for Civil Works approved the project in 1993, but its implementation remains stalled pending an approved plan (http:// www.mvn.usace.army.mil/pao/visitor/index.htm).

My analysis addresses some of the contradictory conclusions about the effects of varying salinity on oyster yields in the Gulf of Mexico-an area whose 2003 production was $69 \%$ and $54 \%$ of the United States oyster landings by weight and dockside value, respectively. The approach used was to collect harvest data for an entire state or estuary and to establish the existence, if any, of positive or negative relationships with river discharge, which was considered a surrogate measure of estuarine salinity. Average yields for an entire estuary, not a particular reef, are examined in this analysis. Five representative estuarine systems were chosen for analysis (Fig. 2). The oyster harvest from Apalachicola Bay, Florida, is about $80 \%$ of the total state harvest (Allen and Turner 1989); the Mobile Bay represents the landings data for Alabama; the landings from the western portion of Mississippi Sound are $>90 \%$ of the state total; and the landings from Galveston Bay are $75-90 \%$ of the state total. The Louisiana harvest is the largest in the Gulf of Mexico, and is from several estuaries whose combined size exceeds that of Chesapeake Bay. Louisiana is also the terminus of the continent's largest river-a truly dominant influence on regional salinity (Wiseman et al. 1990). Because the factors controlling estuarine salinity vary among Louisiana estuaries, and in different ways, the Louisiana estuaries were initially subdivided into watershed units for analysis. The landings data in the 1950 to 2003 National Marine Fisheries Service database for Louisiana could not be consistently and clearly identified with individual watersheds, so some older data were used, principally from the two parishes east of the Mississippi River.

\section{Materials and Methods}

Data on oyster landings (weight of meat) and product value (U.S.\$ or U.S.\$ $\mathrm{kg}^{-1}$ ) for the five Gulf of Mexico states are from the annual reports of the U.S. Fish and Wildlife Service (Commercial Fisheries Series) and the annual Current Fisheries Statistics of the National Marine Fisheries Service (http://www.nmfs.noaa.gov/). These official landings statistics may not completely capture the total landings information for each estuary or state. Landings may be harvested in one state and landed in another without proper attribution, and data on landings by noncommercial efforts are usually absent. The landings data are collected in a systematic way and should, at a minimum, represent a relative estimate of a substantial proportion of the total harvest. Landings data from 1938 to 1951 for the Louisiana parishes of St. Bernard and Plaquemines are from Gunter (1953). Gunter inspected the original state agency files to correct for some errors. He noted that the yield from St. Bernard and Plaquemines parishes in 1937 was $92 \%$ of all landings for Louisiana. These parish-level data were reported in the state agency reports as barrels of oysters-a unit I retained, rather than convert incorrectly for lack of precision.

Data for the annual average stream discharge (1950 to 2003) are from the U.S. Geological Survey (USGS) website (http://nwis.waterdata.usgs.gov/ nwis/). The discharge was computed for the Apalachicola River at Chattahooche, Florida (USGS Station 02358000), the Tombigbee River at Demopolis, Alabama (USGS station 02467), the Pearl River at Monticello, Mississippi (USGS station 24885), and Trinity River near Romayer, Texas (USGS Station 8066500). Data on the discharge for the Mississippi River at Vicksburg, Mississippi, are from the U.S. Corps of Engineers New Orleans District Office. The same office supplied the information on the date, duration, and size of the diversions at the Bonnet Carré.

The data on river discharge and landings volume were averaged to obtain a 3-yr moving average. A rationale for this 3-yr time frame is that oysters reach a marketable size within 18-24 mo in the Gulf of Mexico (Berrigan et al. 1991), and that the harvest may occur for several years thereafter.

The data were normalized to the average value for 1950 to 2003, inclusive, so that the mean value of 

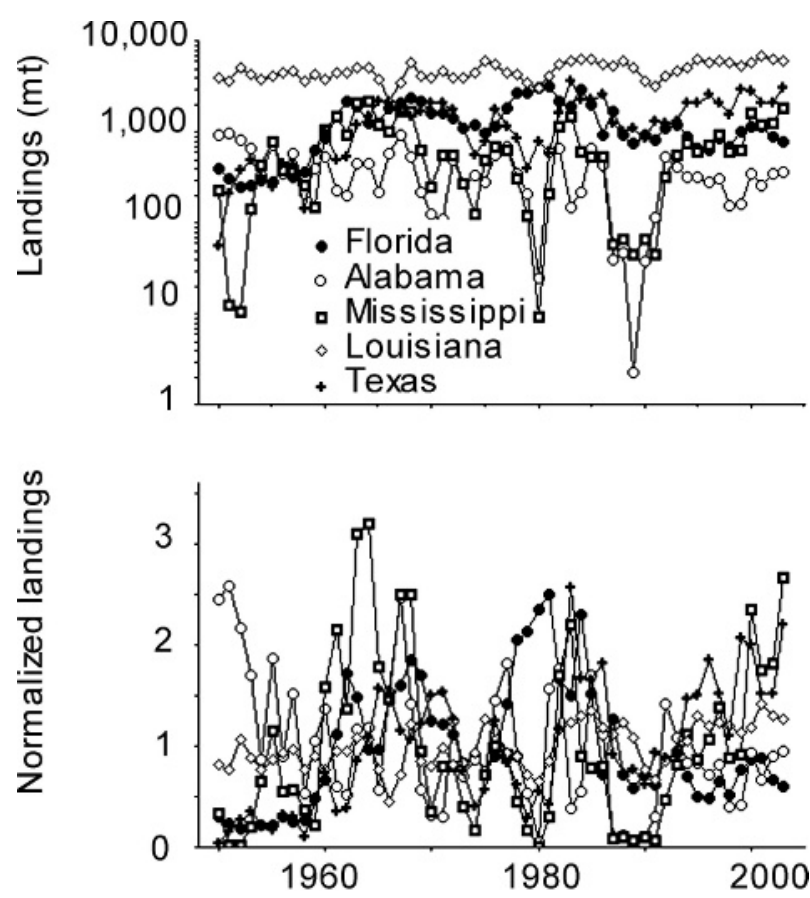

Fig. 3. Oyster landings by state as metric tons (mt; upper panel) and normalized for the average value from 1950 to 2003 $(1=$ mean $)$.

the normalized data is 1.00 . In this way the variance of disparate data sets could be plotted on the same Y axis. The normalized values of the annual landings data for west Florida, Alabama, Louisiana, and Texas were divided by the normalized value of the landings data for the same year for Mississippi. This ratio (state : Mississippi) is an index of the variability in landings in the states immediately adjacent to Mississippi Sound and in each of the two states further away. The changes in these ratios in the $2 \mathrm{yr}$ after opening the Bonnet Carré diversion were compared to the ratio in the year of the diversion.

The data analyses were intended to illuminate any coincidental patterns in the rise or fall of oyster landings as estuarine freshening occurred, as indicated by the variability in local riverine discharge. Statistical analyses were run using a laptop computer statistical package (Abacus Concepts 1987). The simple linear regression analyses were considered significant only if $\mathrm{p}<0.05$.

\section{Results and Discussion}

The landings data for the five states are in the upper panel of Fig. 3, plotted as log transformations to highlight the annual variability. The lower panel has the same values, but they are normalized to the average for each state. The landings for Louisiana represent an average $56 \%$ of the total landings in the Gulf of Mexico from 1950 to 2003. The
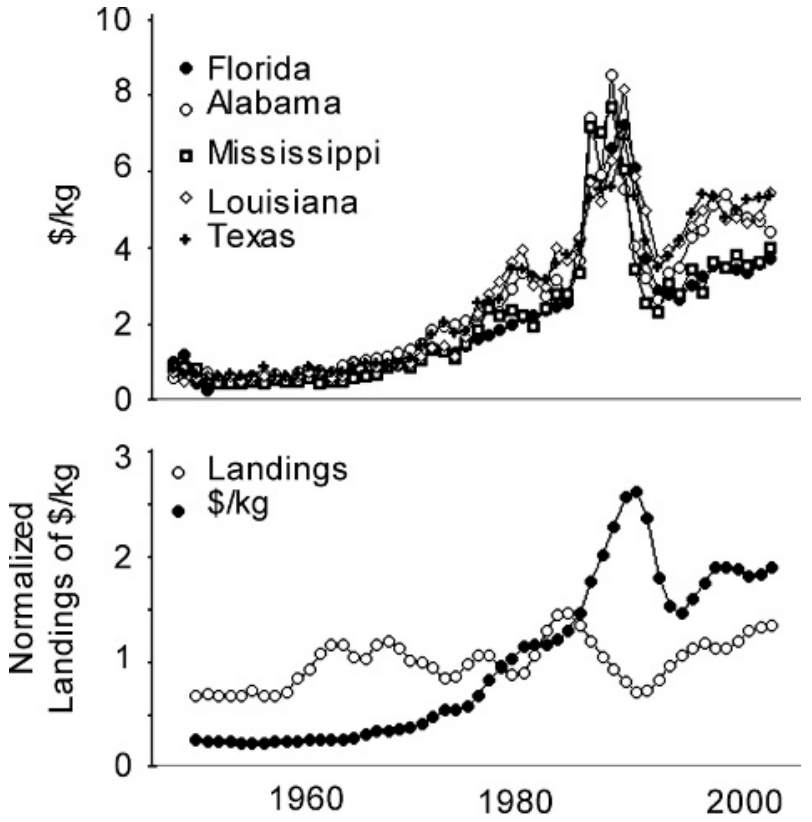

Fig. 4. Three year running average amount and value of oyster landings for the five Gulf of Mexico states normalized for the average value from 1950 to 2003 ( $1=$ mean).

remaining $44 \%$ is divided among West Florida (15\%), Alabama (4\%), Mississippi (8\%), and Texas $(16 \%)$. There is considerable variability in landings ( $>10$ fold) for Mississippi and Alabama, whose landings fluctuations often move coincidentally, and a striking lack of cross-Gulf of Mexico fluctuations among states for any single year. This independence of variability indicates that Gulf of Mexico-wide climatic influences are not an overwhelming factor controlling yields from year to year among all states. An example of a regional factor would be river discharge, which is inversely related to salinity in the Gulf of Mexico estuaries (Turner 2001).

The total landings of oysters in the Gulf of Mexico increased $53 \%$ from the 1950 s to the 1990 s (Fig. 4). An apparent oversupply of oysters in the early 1990s is revealed in the relatively low economic value (U.S.\$ $\mathrm{kg}^{-1}$; Fig. 4). The 2003 average price in the Gulf of Mexico hovers around $\$ 5.30 \mathrm{~kg}^{-1}$. The average value for oysters for the five states from 1950 to 2003 was $\$ 2.14,2.55,2.12,2.66$, and $2.66 \mathrm{~kg}^{-1}$ (Florida, Alabama, Mississippi, Louisiana, and Texas, respectively). This relatively small variability in prices among state does not offer an economic-based interpretation to explain the large variability in landings among states and among years.

The relationships between the variability in the discharge of local rivers and the variability in oyster landings are shown in Figs. 5-7 for the Gulf of 

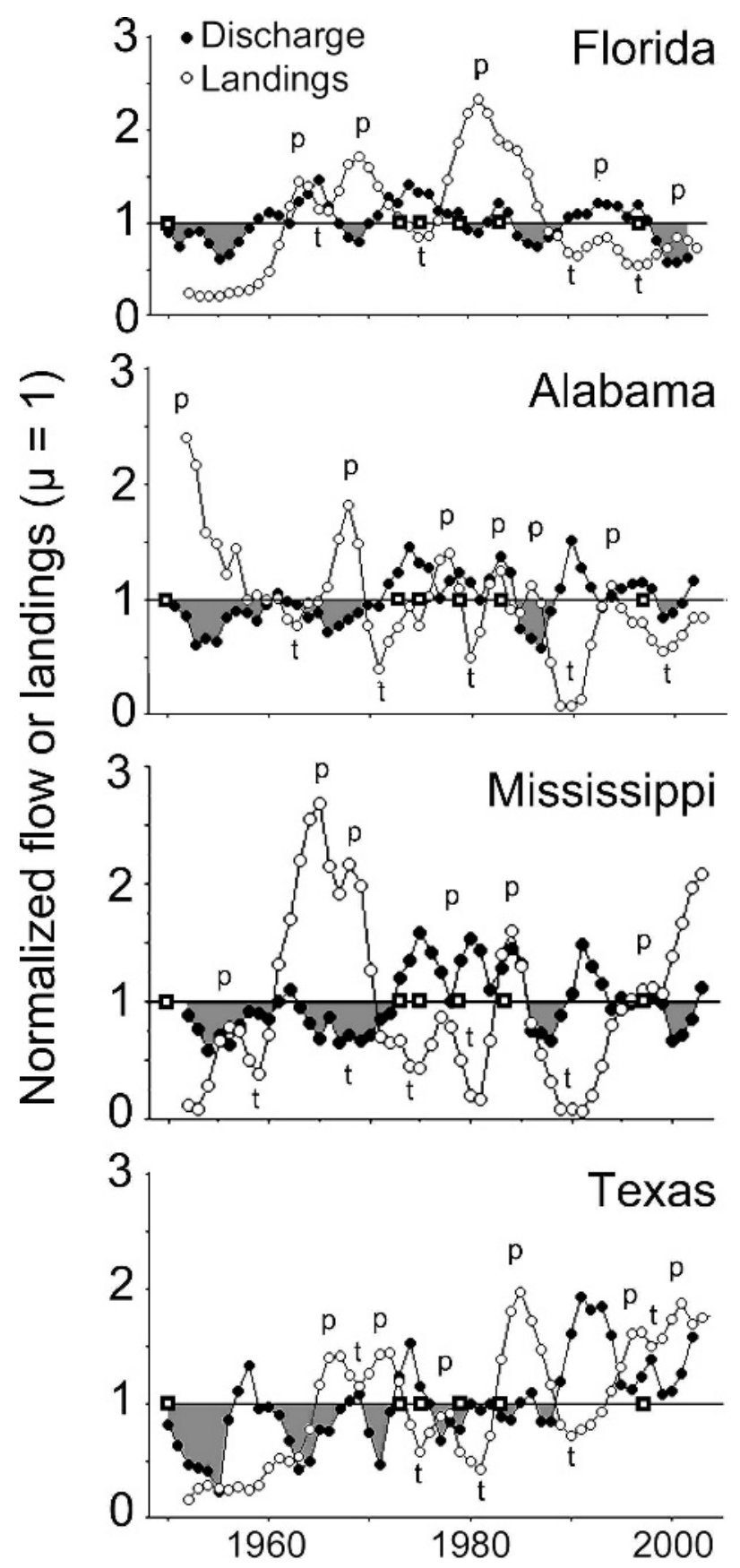

Fig. 5. Three year running average oyster landings in: West Florida and the discharge of the Apalachicola River at Chattahooche (USGS station 02358000), Alabama and the discharge of the Tombigbee River at Demopolis, Alabama (USGS station 02467), Mississippi and the discharge of the Pearl River at Monticello, Mississippi (USGS station 24885), and, Galveston Bay and the discharge of the Trinity River near Romayer, TX (USGS Station 8066500). Both discharge and landings are normalized to the average value for 1950 to 2003 . The shaded area is the belowaverage values for river discharge $(1=$ mean $)$. The squares are the years in which the Bonnet Carré was opened. The $\mathrm{p}$ and $\mathrm{t}$ indicates peaks and troughs, respectively, in landings discussed in the text.

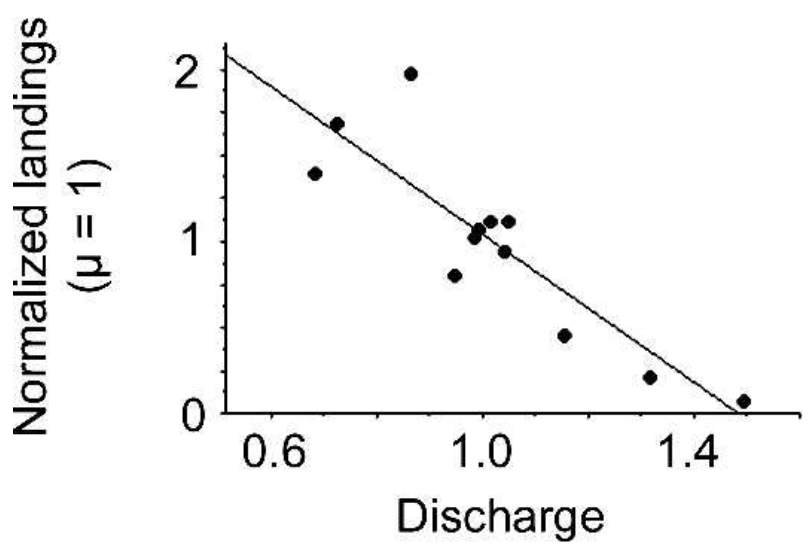

Fig. 6. The relationship between the discharge of the Pearl River, MS, and oysters landings in Mississippi for 1990 to 2003 for the data shown in Fig. 5. A linear regression of the data is shown $\left(\mathrm{Y}=-2.14 \mathrm{X}+3.18 ; \mathrm{R}^{2}=0.77\right)$.

Mexico estuaries, in sequence from east to west. These graphs have the below-average values for landings shaded to help highlight the coincidence, or lack thereof, between the two variables in time. The years when the Bonnet Carré was open is indicated by the square box symbol on the line demarking the average value.

The 3-yr running average of oyster landings in West Florida and the discharge of the Apalachicola River at Chattahooche is shown in Fig. 5. There were five major peaks in oyster landings over the 40$\mathrm{yr}$ record. Four of the five peaks occurred when the river discharge was at a relative low. Four of the four lows in landings happened when there was a relatively high river discharge. Three of the five lows in landings were when the river discharge was rising or had peaked.

The 3-yr running average of oyster landings in Alabama and the discharge of the Tombigbee River at Demopolis, Alabama, are in Fig. 5. Five of the six peaks in landings were matched by a relative low in local river discharge.

The 3-yr running average of oyster landings in Mississippi and the discharge of the Pearl River at Monticello, Mississippi, are in Fig. 5. In general, there is an inverse relationship between the six highs and five lows of the landings values and the lows and highs of the river discharge. The exception is in 1983, when the relative peak of discharge and landings overlapped. The relationship between discharge and landings for 1990 to 2003 (from the data shown in the top panel) are plotted in Fig. 6 as a linear regression $\left(\mathrm{Y}=-2.14 \mathrm{X}+3.18 ; \mathrm{R}^{2}=0.77\right)$, which demonstrates an inverse relationship between the values on the $\mathrm{X}$ and $\mathrm{Y}$ axes.

A different pattern between freshwater inflow and landings emerged for estuarine waters on the east 


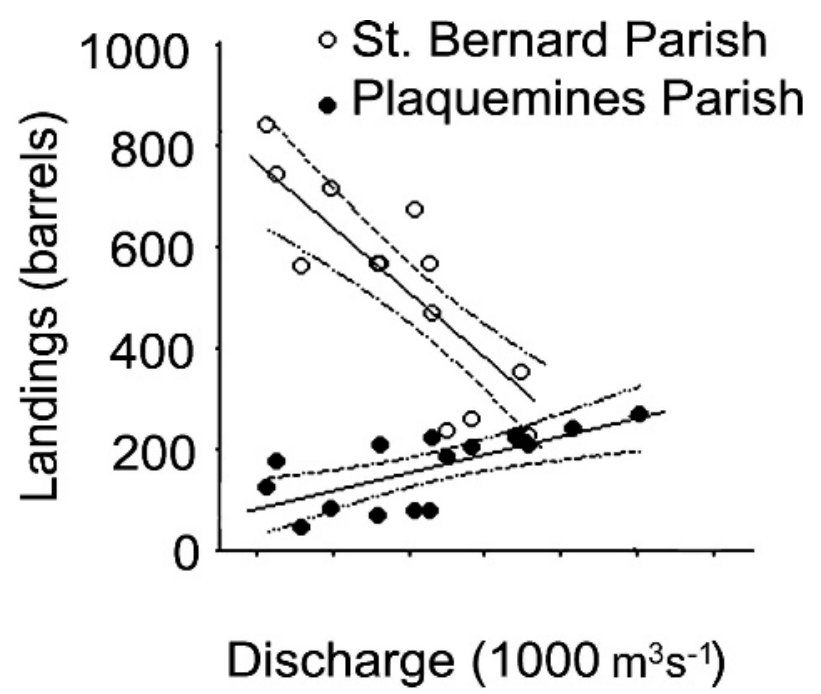

Fig. 7. Three year running average of the discharge of the Mississippi River and the oyster landings in St. Bernard and Plaquemines Parishes from 1936 to 1951. A linear regression of the data is shown, with a $95 \%$ confidence interval for the true value of Y. St. Bernard: $\mathrm{Y}=0.06 \mathrm{X}+1539.1, \mathrm{R}^{2}=0.74$; Plaquemines: $\mathrm{Y}=0.02 \mathrm{X}+127.4, \mathrm{R}^{2}=0.48$. The oyster landings data are from Tables 4 and 5 in Gunter (1953).

side of the Mississippi River (St. Bernard Parish) and the more southern Plaquemines Parish coastal waters located near the mouth of the Mississippi River (Fig. 7). A higher Mississippi River discharge is related to lower landings in St. Bernard coastal waters, but higher values in Plaquemines Parish coastal waters. An inverse relationship between river discharge and landings would exist if the landings were shown as the sum of landings on the east side of the Mississippi River.

A plot of the 3-yr running average of oyster landings in Galveston Bay and the discharge of the Trinity River near Romayer, Texas, is in Fig. 5. All six peaks in landings are matched by lows in the river discharge. All five lows in landings were coincidental with a recent rise or peak in discharge.

In summary, 21 of the 23 peaks in landings in the four states were coincidental with lows in river discharge, and 17 of 19 lows in landings were coincidental with a peak in river discharge. The landings in the fifth state (Louisiana) were also shown to be inversely related to river discharge for the Breton Sound oyster landings of St. Bernard and Plaquemines Parishes.

Figure 8 shows the oyster landings in Mississippi relative to the landings in West Florida, Alabama, Louisiana and Texas for 1950 to 2003. The filled circles are the years in which the Bonnet Carré was open. The relationship of the changes in landings in each state, relative to the landings in Mississippi, are summarized in Table 2. Compared to the

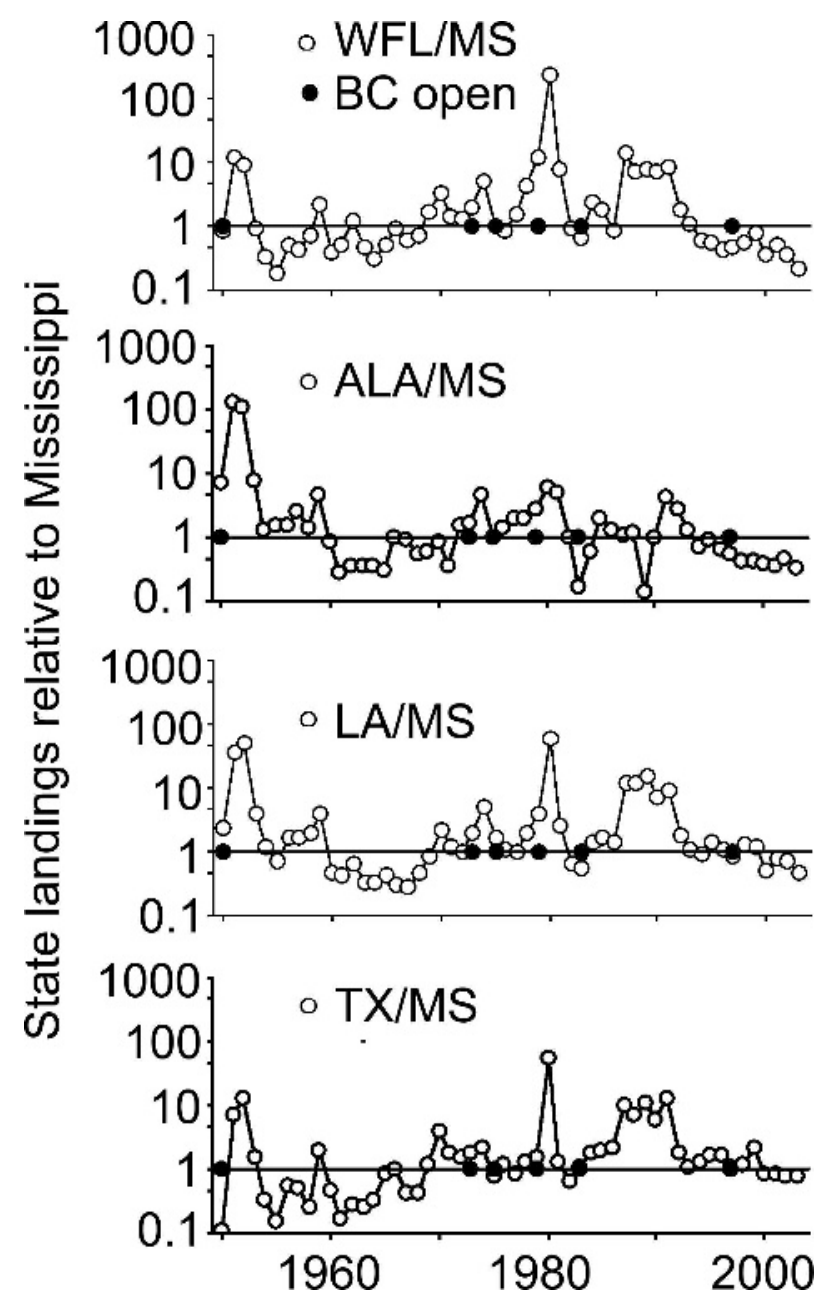

Fig. 8. Oyster landings in Mississippi (MS) relative to the landings in West Florida, Alabama, Louisiana and Texas (WFL, ALA, LA and TX, respectively) for 1950 to 2003. The filled circles are the years in which the Bonnet Carré was open.

landings in the other four states, the landings were lower in Mississippi 25 of 28 times after the Bonnet Carré was opened. The three instances of 28 when landings were not lower in Mississippi after the Bonnet Carré was opened, compared to other states, were in three different years (1973, 1975, and 1997) and in three different states (Alabama, Louisiana, and Texas). In other words, there is no apparent synchrony in the three exceptions in either time or space. The average landings for West Florida, Alabama, Louisiana, and Texas were 8.2, 9.5, 7.4, and 6.8 times higher, respectively, in the $2 \mathrm{yr}$ after the Bonnet Carré was opened compared to landings during the year it was opened.

A general pattern that emerges from this analysis is that the annual variability in oyster landings of the Gulf of Mexico estuaries are, in general, inversely related to freshwater inflow. This conclusion is 
TABLE 2. Changes in oyster landings in the year of the opening of the Bonnet Carre diversion and 2 yr after the diversion was opened, expressed as the landings in west Florida (FL), Alabama (AL), Louisiana (LA), and Texas (TX) relative to the landings in Mississippi (MS). Values in bold are higher after the Bonnet Carré spillway was opened, compared to the year of the opening (25 of 28 times).

\begin{tabular}{|c|c|c|c|c|c|c|c|}
\hline Diversion Year & & FL : MS & AL : MS & LA : MS & $\mathrm{TX}: \mathrm{MS}$ & Average & $\pm 1 \mathrm{SD}$ \\
\hline \multirow[t]{2}{*}{1937} & Before & 0.07 & 0.10 & 0.62 & 0.09 & 0.22 & 0.27 \\
\hline & After & 0.24 & 0.39 & 3.16 & 0.26 & 1.01 & 1.43 \\
\hline \multirow{2}{*}{1950} & Before & 0.88 & 7.21 & 2.41 & 0.12 & 2.66 & 3.18 \\
\hline & After & 10.75 & 119.25 & 46.00 & 10.50 & 46.63 & 51.21 \\
\hline \multirow[t]{2}{*}{1973} & Before & 2.05 & 1.71 & 2.05 & 1.85 & 1.91 & 0.17 \\
\hline & After & 3.10 & 2.94 & 3.50 & 1.51 & 2.76 & 0.87 \\
\hline \multirow[t]{2}{*}{1975} & Before & 1.03 & 1.04 & 1.78 & 0.79 & 1.16 & 0.43 \\
\hline & After & 1.22 & 1.72 & 1.09 & 1.08 & 1.28 & 0.30 \\
\hline \multirow[t]{2}{*}{1979} & Before & 11.89 & 3.00 & 4.00 & 1.61 & 5.12 & 4.61 \\
\hline & After & 122.03 & 5.53 & 33.87 & 28.68 & 47.53 & 51.18 \\
\hline \multirow[t]{2}{*}{1983} & Before & 0.68 & 0.18 & 0.56 & 1.16 & 0.65 & 0.40 \\
\hline & After & 2.24 & 1.39 & 1.57 & 1.97 & 1.79 & 0.38 \\
\hline \multirow[t]{3}{*}{1997} & Before & 0.47 & 0.59 & 0.89 & 1.09 & 0.76 & 0.28 \\
\hline & After & 0.72 & 0.46 & 1.29 & 1.75 & 1.05 & 0.58 \\
\hline & & & & & & & All Values \\
\hline \multirow{2}{*}{ Average } & Before & 2.44 & 1.98 & 1.76 & 0.96 & & 1.78 \\
\hline & After & 20.04 & 18.81 & 12.93 & 6.53 & & 14.58 \\
\hline \multirow[t]{2}{*}{ $\pm 1 \mathrm{SD}$} & Before & 4.21 & 2.52 & 1.23 & 0.68 & & 2.47 \\
\hline & After & 45.12 & 44.33 & 18.80 & 10.36 & & 31.96 \\
\hline
\end{tabular}

supported by the inverse relationships between landings and discharge in the five states, and for the relative changes in landings in Mississippi Sound estuaries, compared to the other Gulf of Mexico states. When the Bonnet Carré is opened, which is when the Mississippi River discharge is relatively high, then landings decrease in Louisiana for the next several years, and the decrease there is disproportionately lower than in Mississippi coastal waters. The exception to this general pattern occurs in the case of the landings from Plaquemines Parish coastal waters. In that single case there are higher landings with greater discharge of the Mississippi River.

I conclude that the position of most Gulf of Mexico estuaries in Fig. 1 is represented by Line C: oyster yields decline as estuarine salinity is lowered; higher average estuarine salinity is associated with higher oyster harvests. If the above is an acceptable conclusion, then the benefits of diverting water into Mississippi Sound, and the rationale for doing so, cannot be supported by an anticipated higher yield in oysters by either the Mississippi or Louisiana oyster industries.

This analysis focused on the effects of variable salinity on commercial oyster yields. Many other factors also influence yields, including effort, equipment, season length, water quality, and consumer preferences. The Gulf of Mexico oyster fisheries, like many fisheries, are under pressure from urban encroachment, overfishing, and eutrophication (Kirby 2004). Estuarine management is more than about managing just one exploited renewable resource. Manipulating estuarine salinity in the Gulf of Mexico estuaries using a river diversion, regardless of its effect on the oyster fisheries, should be done within the context of the whole estuary and not just part of the estuary. To understand the natural fluctuations in salinity involves an understanding of the temporal and spatial elements of an interdependent suite of biological, geological, physical, and social factors, which generate sustainable and healthy ecosystems and not just an understanding of part of the system.

\section{ACKNOWLEDGMENTS}

This analysis was supported by a National Oceanic and Atmospheric Administration Coastal Ocean Program MULTISTRESS Award No. NA16OP2670. I thank E. Powell, R. Mann, and N. N. Rabalais for their constructive review of manuscript drafts.

\section{Literature Cited}

Abacus Concepts. 1987. StatView II. Abacus Concepts Inc., Berkeley, California.

Allen, R. L. AND R. E. TuRnER. 1989. Environmental influences on the oyster industry along the west coast of Florida. Journal of Shellfish Research 8:95-104.

Berrigan, M., T. Candis, J. Cirino, R. Dugas, C. Dyer, J. Gray, T. Herrington, W. Keithly, R. Leard, J. R. Nelson, and M. van Hoose. 1991. The oyster fishery of the Gulf of Mexico, United States: A regional management plan. No. 24. Gulf States Marine Fisheries Commission, Ocean Springs, Mississippi.

Butler, P. A. 1949. An investigation of oyster producing areas in Louisiana and Mississippi damaged by flood waters in 1945 . U.S. Fish and Wildlife Service, Special Scientific Report: Fisheries No. 8, Washington, D.C.

ButLer, P. A. 1952. Effect of floodwaters on oysters in Mississippi Sound in 1950. U.S. Fish and Wildlife Service Research Report 31, Washington, D.C.

Butler, P. A. 1954. Summary of our knowledge of the oyster in the Gulf of Mexico. U.S. Fish and Wildlife Service Bulletin 55:479489 .

Butler, P. A. And J. B. Engle. 1950. The 1950 opening of the Bonnet Carré spillway: Its effect on oysters. U.S. Fish and 
Wildlife Service, Special Scientific Report: Fisheries 14, Washington, D.C.

Etzold, D. J. And D. C. Williams. 1974. Data relative to the introduction of supplemental fresh water under periodic controlled conditions for the purpose of enhancing seafood productivity in Mississippi and Louisiana estuaries. MississippiAlabama Sea Grant Consortium Report. COM-75-10061. Ocean Springs, Mississippi.

Galtsoff, P. S. 1930. Destruction of oyster bottoms in Mobile Bay by the flood of 1924. U.S. Bureau of Fisheries, Report Commissioner of Fisheries for 1929, Appendix 11. Document 1069, Washington, D.C.

GunTER, G. 1953. The relationship of the Bonnet Carré spillway to oyster beds in Mississippi Sound and the "Louisiana Marsh," with a report on the 1950 opening. Contributions in Marine Sciences 3:17-71.

Hofstetter, R. P. 1981. Rehabilitation of public oyster reefs damaged or destroyed by a natural disaster. Texas Parks and Wildlife Department, Coastal Fisheries Branch, Management Data Series No. 21, Austin, Texas.

KiRBY, M. X. 2004. Fishing down the coast: Historical expansion and collapse of oyster fisheries along continental margins. Proceeding of the National Academy of Sciences (USA) 101:1309613099.

MarwitZ, S. R. AND C. E. BRYAN. 1990. Rehabilitation of public oyster reefs damaged by a natural disaster in San Antonio Bay. Texas Parks and Wildlife Department, Coastal Fisheries Branch, Management Data Series no. 32, Austin, Texas.

MaY, E. B. 1972. The effect of flood water on oysters in Mobile Bay. Proceedings National Shellfisheries Association 62:67-71.
Pierce, M. E. AND J. T. Conover. 1954. A study of the growth of oysters under different ecological conditions in Great Pond. Biological Bulletin 107:318.

Powell, E. N., J. M. Klinck, E. E. Hofmann, and M. A. McManus. 2003. Influence of water allocation and freshwater inflow on oyster production: A hydrodynamic-oyster population model for Galveston Bay, Texas, USA. Environmental Management 31: $100-121$.

TurneR, R. E. 2001. Of manatees, mangroves, and the Mississippi River: Is there an estuarine signature for the Gulf of Mexico? Estuaries 24:139-150.

Turner, R. E., Q. Dortch, D. Justic', and E. M. Swenson. 2002. Nitrogen loading into an urban estuary: Lake Pontchartrain (Louisiana, USA). Hydrobiologia 487:137-152.

Ulanowicz, R. E., W. C. Caplins, and E. A. Dunnington. 1980. The forecasting of oyster harvest in central Chesapeake Bay. Estuarine Coastal and Marine Science 11:101-106.

U.S. Congress House. 1948. Rehabilitation of oyster beds: Hearings before the Committee on Flood Control, House of Representatives, Seventy-ninth Congress, second session on H.R. 3888: A bill authorizing appropriation for rehabilitating the oyster beds destroyed by the opening of the Bonnet Carré spillway, and for other purposes, May 14 and 15, 1946. U.S. Government Print Office, Washington, D.C.

ViosCA, JR., P. 1938. Effect of the Bonnet Carré spillway on fisheries. Louisiana Conservation Review Winter, 51-53.

Wiseman, JR., W. J., E. M. Swenson, And J. Power. 1990. Salinity trends in Louisiana estuaries. Estuaries 13:265-271.

Received, September 14, 2005 Accepted, January 11, 2006 